\title{
Effects of low light intensities at night on nitrate accumu- lation in lettuce grown on a recirculating nutrient solution
}

\author{
E. G. STEINGROVER', J. W. STEENHUIZEN \& J. VAN DER BOON
}

DLO-Institute for Soil Fertility Research, Haren. Netherlands

' Present address: DLO-Institute for Forestry and Nature Research, P.O. Box 23, NL 6700 AA Wageningen, Netherlands

Received 3 July 1992; accepted 25 September 1992

\begin{abstract}
During winter, when light intensities are low, high nitrate concentrations often occur in leafy vegetables. This is undesirable from the viewpoint of public health. With lettuce grown on a recirculating nutrient solution the effects of low lighting during the night in combination with nutrient factors and solution temperature on the nitrate concentration were studied. The experiment showed that lettuce could be grown during winter under glass with a nitrate concentration as low as $2900 \mathrm{mg} / \mathrm{kg}$ fresh weight; this is much lower than the maximum permissible concentration for winter-grown lettuce in the Netherlands of $4500 \mathrm{mg} / \mathrm{kg}$. The lowest nitrate concentration, without negative effects on yield or quality, was obtained by growing the crop on recirculating nutrient solutions with an initial ammonium:nitrate ratio of 0.25 , with a change to a ratio of 1.0 for the last two weeks. The addition of chloride did not affect the nitrate concentration. Raising the temperature of the nutrient solution at night to $10^{\circ} \mathrm{C}$ in combination with a lower minimum air temperature of $6^{\circ} \mathrm{C}$ to reduce energy consumption, stimulated growth, but also increased the lettuce nitrate concentration by an average of $360 \mathrm{mg} / \mathrm{kg}$. Supplying light of a low intensity at a photon flux density of $27 \mu \mathrm{mol} \mathrm{E} \mathrm{m} \mathrm{m}^{-2} \mathrm{~s}^{-1}$ $(400-700 \mathrm{~nm})$ at night for up to 8 nights before harvest did not further reduce the nitrate concentration on a fresh weight basis because the dry matter percentage increased.
\end{abstract}

Keywords: nitrate concentration, lettuce, recirculating nutrient solution (NFT). nitrogen source, chloride, temperature of solution, lighting

\section{Introduction}

High nitrate concentrations in vegetables are undesirable in respect of public health. because they may cause methaemoglobinaemia and can form carcinogenic nitrosamines after consumption (Steingröver, 1986). Leafy vegetables grown without artificial light in winter in glasshouses usually contain high nitrate concentrations, which often exceed the maximum permissible level of $4500 \mathrm{mg}$ nitrate per $\mathrm{kg}$ fresh weight (Roorda van Eysinga. 1984). Supplying artificial light of sufficient intensity and duration during the lifetime of the plant may increase the fresh weight of lettuce and 
lower its nitrate concentration (Quinche, 1983), but the cost involved is prohibitive.

In a number of experiments (Van der Boon et al., 1990) conducted with lettuce grown on recirculating nutrient solutions in a glasshouse without artificial light, replacement of $20 \%$ of the nitrate in the solution by ammonium decreased the nitrate concentration of the crop, without affecting yields. In the ammonium treatments in those experiments chloride partly replaced nitrate as an anion, and this may have contributed to the reduced nitrate concentration (Blom-Zandstra \& Lampe. 1983). Supplying additional $\mathrm{Cl}^{-}$without changing the nitrate concentration in the solution further lowered the nitrate concentration of the lettuce, provided that $\mathrm{NH}_{4}{ }^{+}$was present as well (Van der Boon et al., 1988). The $\mathrm{NO}_{3}{ }_{3}$ concentration in winter-grown lettuce was thus reduced to $2900 \mathrm{mg} / \mathrm{kg}$ fresh weight (Van der Boon et al., 1990), well below the current maximum permissible value, but further reductions are desirable.

Compared with conventional practice, energy can be saved in glasshouses in winter by raising the temperature of the nutrient solution and lowering of the glasshouse air temperature at night. A disadvantage of the higher solution temperature is the possibility of a greater nitrate uptake in comparison with that of ammonium (Frota \& Tucker, 1972; Clarkson \& Warner, 1979; MacDuff \& Wild, 1989; Van der Boon et al., 1990).

For spinach, it was shown that the nitrate concentration of the leaves could be decreased by $25 \%$ by low intensity illumination at a photon flux density of $35 \mu \mathrm{mol}$ $\mathrm{E} \mathrm{m}^{-2} \mathrm{~s}^{-1}$ for one single night. During this treatment the nitrate uptake by the roots did not increase as much as under normal growing conditions and more nitrate in the plant was reduced, leading to a lower nitrate concentration in the morning (Steingröver et al., 1986a, 1986b).

The present experiment was carried out firstly to determine if low intensity illumination at night would be effective in lowering the nitrate concentration of lettuce heads and secondly to combine it with the solution treatments found to give the lowest nitrate concentrations in the lettuce heads. Compared to spinach, however, the larger plant mass of lettuce and its closed heads, could impair or even prevent the beneficial effect of low light at night. Therefore the plants were illuminated for several nights rather than only one, as had been found effective for spinach. Additional purposes of the experiment were to analyse further the interaction between ammonium and chloride supply on nitrate concentrations in the crop and also to analyse the effect of energy saving measures on the nitrate concentration of the lettuce heads.

\section{Materials and methods}

Lettuce (Lactuca sativa capitata L.), cultivar Panvit, was propagated on peat blocks and planted in two glasshouse compartments on 11 December 1985 in a Nutrient Film Technique system. Each compartment contained 48 gullies, with 13 plants per gully. The experimental treatments were factorial combinations of a) initial nutrient solutions, b) final solutions, c) heating of the nutrient solutions and d) supplemental light at night. The experiment consisted of two replications (= two compartments). 
For technical reasons, light and heating had to be laid out in blocks within which solution treatments were randomly grouped.

a) Four initial nutrient solutions were used. Solution $A$ contained nitrate as the sole source of nitrogen, at $10 \mathrm{mmol} \mathrm{N}$ per litre. Solutions B, C and D contained $8 \mathrm{mmol}$ nitrate- $\mathrm{N}$ per litre and various amounts of ammonium and chloride (Table 1).

b) On 4 February 1986, two weeks before the first harvest of marketable heads, one-third of all initial treatments was changed to a solution with a higher chloride concentration (solution E) and another third to a solution with a higher ammonium concentration (solution $\mathrm{F}$ ), both at a nitrate-N level of $4 \mathrm{mmol}$ per litre (Table 1). In all solutions the EC was $1.3 \mathrm{mS} \mathrm{cm}{ }^{-1}: \mathrm{H}_{2} \mathrm{PO}_{4}{ }^{\circ}$ and $\mathrm{SO}_{4}{ }^{2-}$ were always supplied in a molar ratio of $1: 0.5 ; \mathrm{K}^{+}, \mathrm{Ca}^{2+}$ and $\mathrm{Mg}^{2+}$ in molar ratios of $10: 4.5: 1.5$. The nutrient solutions were replaced each week or earlier if the nitrate concentration dropped below $4 \mathrm{mmol}$ per litre for the 10 or $8 \mathrm{mmol} \mathrm{N}$ per litre or to $2 \mathrm{mmol}$ for the $4 \mathrm{mmol}$ $\mathrm{N}$ per litre. The $\mathrm{pH}$ and $\mathrm{EC}$ of the recirculating solutions were checked daily. $\mathrm{pH}$ values outside the range of 5.0-7.0 were adjusted to 6.0 with solutions of bases or acids in above given ionic ratios. When the EC fell below $0.8 \mathrm{mS} \mathrm{cm}^{-1}$ the values were brought up to $1.3 \mathrm{mS} \mathrm{cm}^{-1}$, using concentrated nutrient solutions. Microelements were given in quantities considered to be sufficient for good growth; B 32.7, $\mathrm{Zn} \mathrm{2.0,} \mathrm{Cu} \mathrm{0.5,} \mathrm{Mn} \mathrm{2.5,} \mathrm{Mo} 0.2$ and Fe-(EDTH) $44.7 \mu \mathrm{mol}$ per litre. During the daytime carbon dioxide was maintained at a concentration of $0.10-0.13 \%(\mathrm{vol} / \mathrm{vol})$.

c) The nutrient solution of half of the gullies was heated during the night to $10^{\circ} \mathrm{C}$. The other half followed the ambient air temperature, i.e. minimum $6{ }^{\circ} \mathrm{C}$ at night and $12^{\circ} \mathrm{C}$ during the day.

d) Commencing on 18 February 1986, half of each of the glasshouse compartments was illuminated during the night from 17.00 to $8.00 \mathrm{~h}$. Three lamps, Philips $\mathrm{HPI} / \mathrm{T} 400 \mathrm{~W}$, were installed at $122 \mathrm{~cm}$ height, lighting a total surface of $650 \times$ $300 \mathrm{~cm}$ with a low light intensity at a photon flux density of $27 \mu \mathrm{mol} \mathrm{E} \mathrm{m} \mathrm{m}^{-2} \mathrm{~s}^{-1}$ $(400-700 \mathrm{~nm})$. The other half was protected against light by shading the plants using black plastic foil in such a way that the distance between the plants and the plastic was at least $50 \mathrm{~cm}$.

Table I. Composition of the nutrient solutions (A-F) (mmol/ ).

\begin{tabular}{|c|c|c|c|c|c|c|}
\hline & \multicolumn{4}{|c|}{ Initial solutions } & \multicolumn{2}{|c|}{$\begin{array}{l}\text { Extra solutions } \\
\text { during last } \\
3 \text { weeks }\end{array}$} \\
\hline & A & B & C & D & $\bar{E}$ & $F$ \\
\hline $\begin{array}{l}\mathrm{NO}_{3} \\
\mathrm{NH}_{4}^{+}\end{array}$ & $\begin{array}{r}10 \\
0\end{array}$ & $\begin{array}{l}8 \\
2\end{array}$ & $\begin{array}{l}8 \\
0\end{array}$ & $\begin{array}{l}8 \\
1\end{array}$ & $\begin{array}{l}4 \\
2\end{array}$ & $\begin{array}{l}4 \\
4\end{array}$ \\
\hline $\begin{array}{l}\mathrm{Cl}^{\circ} \\
\mathrm{SO}_{4}{ }^{2} \\
\mathrm{H}_{2} \mathrm{PO}_{4}\end{array}$ & $\begin{array}{l}0 \\
0.38 \\
0.75\end{array}$ & $\begin{array}{l}0 \\
0.88 \\
1.75\end{array}$ & $\begin{array}{l}2 \\
0.38 \\
0.75\end{array}$ & $\begin{array}{l}1 \\
0.63 \\
1.25\end{array}$ & $\begin{array}{l}4 \\
0.88 \\
1.75\end{array}$ & $\begin{array}{l}2 \\
1.38 \\
2.75\end{array}$ \\
\hline $\begin{array}{l}\mathrm{K}^{+} \\
\mathrm{Ca}^{2+} \\
\mathrm{Mg}^{2+}\end{array}$ & $\begin{array}{l}5.23 \\
2.35 \\
0.79\end{array}$ & $\begin{array}{l}4.32 \\
1.95 \\
0.65\end{array}$ & $\begin{array}{l}5.23 \\
2.36 \\
0.79\end{array}$ & $\begin{array}{l}4.77 \\
2.15 \\
0.72\end{array}$ & $\begin{array}{l}4.32 \\
1.95 \\
0.65\end{array}$ & $\begin{array}{l}2.41 \\
1.54 \\
0.51\end{array}$ \\
\hline
\end{tabular}




\section{E. G. STEINGRÖVER, J. W. STEENHUIZEN AND J. VAN DER BOON}

The first harvest was on the aftemoon of 18 February 1986 before the start of supplementary illumination. Four randomly selected heads were sampled per gully to determine the lettuce nitrate levels for the different treatments, until then grown under the same light conditions. On the mornings of 19.23 and 26 February 1986 the 2nd to 4th harvests took place (three heads per gully), when the plants had experienced 1,5 or 8 nights of low light or had received none. After removal of rotten and withered bottom leaves, fresh and dry weights of the marketable heads were determined. The head samples were analysed for total N, nitrate and chloride. Nitrate was determined using the o-xylenol method, total nitrogen using the salicylate method, and reduced $\mathrm{N}$ by difference.

\section{Results}

\section{Effects of initial nutrient solution}

The results of the first harvest, carried out just prior to supplementary illumination, are shown in Table 2. Partial replacement of $10 \mathrm{mmol}$ nitrate per litre by $2 \mathrm{mmol}$ ammonium in the initial solution increased fresh head weight. The dry matter percentage was highest for the $10 \mathrm{mmol}$ nitrate solution and lowest for the solution in which $2 \mathrm{mmol}$ nitrate was replaced by equal amounts of ammonium and chloride. Ammonium decreased the nitrate concentration of the lettuce, but chloride did not. Replacement of nitrate by ammonium and chloride together had an intermediate effect.

Table 2. Weight (g per head) and nutrient concentration of lettuce heads at first harvest. as affected by the initial nutrient solutions (A-D).

\begin{tabular}{|c|c|c|c|c|c|c|c|}
\hline \multirow{3}{*}{ Weight or concentration } & \multirow{3}{*}{$\begin{array}{l}10 \mathrm{mmol}^{-3} \mathrm{I}^{-1} \\
\frac{\mathrm{A}}{}\end{array}$} & \multicolumn{3}{|c|}{$8 \mathrm{mmol} \mathrm{NO}_{3} \mathrm{l}^{-1}$} & \multicolumn{3}{|c|}{$\begin{array}{l}\text { Stat. eval. of effect of } \\
\text { nutrient solutions* }\end{array}$} \\
\hline & & $\begin{array}{l}2 \mathrm{mmol}^{+} \\
\mathrm{NH}_{4}^{+} \mathrm{I}^{-1}\end{array}$ & $\begin{array}{l}2 \mathrm{mmol}^{-1} \\
\mathrm{Cl}^{-1}\end{array}$ & $\begin{array}{l}1 \mathrm{mmol} \mathrm{NH}_{4}^{+} \\
1 \mathrm{mmol} \mathrm{Cl} \mathrm{I}^{\prime}\end{array}$ & & & \\
\hline & & B & C & D & $\mathrm{NH}_{4}{ }^{*}$ & $\mathrm{Cl}^{-}$ & $\mathrm{NH}_{4}^{+}+\mathrm{Cl}^{-}$ \\
\hline $\begin{array}{l}\text { Dry weight } \\
\text { Dry weight (\%) }\end{array}$ & $\begin{array}{l}6.18 \\
4.97\end{array}$ & $\begin{array}{l}6.65 \\
4.88\end{array}$ & $\begin{array}{l}6.10 \\
4.90\end{array}$ & $\begin{array}{l}6.21 \\
4.82\end{array}$ & + & + & - \\
\hline $\begin{array}{l}\text { Total } \mathrm{N}\left(\mathrm{mmol} \mathrm{kg}^{-1}\right) \\
\mathrm{NO}_{3}^{-}\left(\mathrm{mmol} \mathrm{kg}^{-1}\right) \\
\mathrm{Cl}^{-1}(\mathrm{mmol} \mathrm{kg}) \\
\text { Reduced } \mathrm{N}\left(\mathrm{mmol} \mathrm{kg}^{-1}\right) \\
\left(\mathrm{NO}_{3}^{+}+\mathrm{Cl}^{-1}\right)\left(\mathrm{mmol} \mathrm{kg}^{-1}\right)\end{array}$ & $\begin{array}{r}4133 \\
1204 \\
195 \\
2928 \\
1399\end{array}$ & $\begin{array}{r}4268 \\
1101 \\
222 \\
3167 \\
1323\end{array}$ & $\begin{array}{r}4211 \\
1217 \\
289 \\
2994 \\
1506\end{array}$ & $\begin{array}{r}4243 \\
1143 \\
+354 \\
3100 \\
1498\end{array}$ & $\begin{array}{l}++ \\
++ \\
++ \\
+ \\
+\end{array}$ & $\begin{array}{l}(+) \\
++ \\
+ \\
++\end{array}$ & $\begin{array}{l}- \\
- \\
++\end{array}$ \\
\hline $\begin{array}{l}\text { Fresh weight } \\
\mathrm{NO}_{3}^{\circ}\left(\mathrm{mg} \mathrm{kg}{ }^{-1}\right)\end{array}$ & $\begin{array}{r}125 \\
3700 \\
\end{array}$ & $\begin{array}{r}137 \\
3324\end{array}$ & $\begin{array}{r}125 \\
3700\end{array}$ & $\begin{array}{r}129 \\
3411 \\
\end{array}$ & $\begin{array}{l}+ \\
+++\end{array}$ & $\begin{array}{l}- \\
++\end{array}$ & - \\
\hline
\end{tabular}

- is not significant; $(+) P=0.10:+P=0.05 ;++P=0.01 ;+++P=0.001$ 
Neither fresh weight, dry weight nor percentage dry weight of the heads was unfavourably affected by changing the ratio $\mathrm{NO}_{3}: \mathrm{NH}_{4}{ }^{+}: \mathrm{Cl}^{-}$of the solutions two weeks before the first harvest (Table 3). Replacement of nitrate in the initial solution by $\mathrm{NH}_{4}^{+}$did decrease the nitrate concentration of the lettuce however. The highest $\mathrm{Cl}$ concentration of the heads was found when the plants were first grown on $1 \mathrm{mmol}$ $\mathrm{Cl}^{+}$and $1 \mathrm{mmol} \mathrm{NH}_{4}^{+}$and later on $2 \mathrm{mmol} \mathrm{Cl}^{-}$and $4 \mathrm{mmol} \mathrm{NH}_{4}^{+}$per litre (data not given).

\section{Heating of the nutrient solution}

Lettuce grew better in the heated nutrient solution, resulting in increased fresh and dry weights with a lower percentage of dry matter (Table 4), while leaf colour was somewhat lighter. The nitrate concentration on a fresh and dry weight basis was higher, while the amount of reduced nitrogen was not affected. Heating the nutrient solution also resulted in a slightly increased Clconcentration in the lettuce heads.

\section{Illumination at night}

Fresh weight of the lettuce heads was not affected by supplementary illumination of low intensity for several nights (Table 5). Dry weight, however, increased due to the illumination, especially that of the plants on the unheated solution (data of very significant interaction not given). The dry matter percentage was higher in the illuminated plants. The nitrate concentration in dry matter was reduced by the lighting, but

Table 3, Weight (g per head) and nutrient concentration of lettuce heads at the first harvest, as affected by the final nutrient solutions (A-F).

\begin{tabular}{|c|c|c|c|c|c|}
\hline \multirow[t]{3}{*}{ Weight or concentration } & \multicolumn{3}{|c|}{$\begin{array}{l}\text { Nutrient solutions at end of } \\
\text { growing period }\end{array}$} & \multirow{2}{*}{\multicolumn{2}{|c|}{$\begin{array}{l}\text { Stat. eval. } \\
\text { of effect of } \\
\text { nutrient solutions }\end{array}$}} \\
\hline & unchanged & $\begin{array}{l}\text { changed to } \\
4 \mathrm{mmol} \mathrm{NO}_{3} \text {. } \\
2 \mathrm{mmol} \mathrm{NH}_{4} \\
4 \mathrm{mmol} \mathrm{Cl}^{-1}\end{array}$ & $\begin{array}{l}4 \mathrm{mmol} \mathrm{NO}_{3}{ }^{-} \mathrm{mmol} \mathrm{NH}_{4} \\
2 \mathrm{mmol} \mathrm{Cl}^{-1}\end{array}$ & & \\
\hline & $\overline{A-D}$ & $E$ & $F$ & $\mathrm{NH}_{4}{ }^{+}$ & $\mathrm{Cl}$ \\
\hline 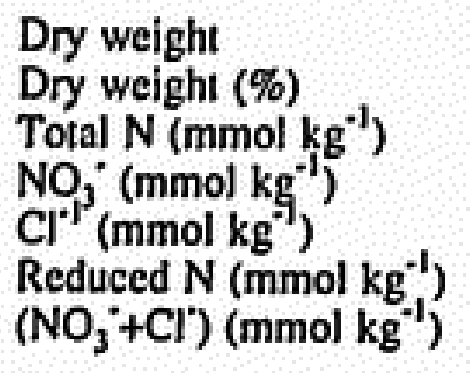 & $\begin{array}{l}6.30 \\
4.91 \\
4230 \\
1368 \\
123 \\
2863 \\
1491\end{array}$ & $\begin{array}{r}6.30 \\
4.91 \\
4109 \\
1160 \\
324 \\
2949 \\
1484\end{array}$ & \begin{tabular}{r|}
6.25 \\
4.85 \\
4302 \\
972 \\
349 \\
3330 \\
1321
\end{tabular} & $\begin{array}{l}\text { - } \\
- \\
+++ \\
++ \\
++ \\
++ \\
++\end{array}$ & $\begin{array}{l}\text { n } \\
- \\
+ \\
+ \\
++ \\
++\end{array}$ \\
\hline $\begin{array}{l}\text { Fresh weight } \\
\mathrm{NO}_{3}^{*} \text { (mg kg }{ }^{-1} \text { ) }\end{array}$ & $\begin{array}{r}129 \\
4155\end{array}$ & $\begin{array}{r}129 \\
3527\end{array}$ & $\begin{array}{r}129 \\
2920\end{array}$ & $e_{+++}^{2}$ & - \\
\hline
\end{tabular}




\section{E. G. STEINGROVER, J. W. STEENHUIZEN AND J. VAN DER BOON}

Table 4. Weight ( $\mathrm{g}$ per head) and nutrient concentration of lettuce heads at the first harvest as affected by heating the nutrient solutions.

\begin{tabular}{|c|c|c|c|}
\hline Weight or concentration & Unheated & Heated & $\begin{array}{l}\text { Stat. eval. } \\
\text { of heating }\end{array}$ \\
\hline $\begin{array}{l}\text { Dry weight } \\
\text { Dry weight (\%) }\end{array}$ & $\begin{array}{l}5.96 \\
4.99\end{array}$ & $\begin{array}{l}6.61 \\
4.80\end{array}$ & $\stackrel{++}{++}$ \\
\hline $\begin{array}{l}\text { Total } \mathrm{N}\left(\mathrm{mmol} \mathrm{kg}^{-1}\right) \\
\mathrm{NO}_{3}^{-}(\mathrm{mmol} \mathrm{kg}) \\
\mathrm{Cl}^{-1}(\mathrm{mmol} \mathrm{kg}) \\
\text { Reduced } \mathrm{N}\left(\mathrm{mmol} \mathrm{kg}^{-1}\right) \\
\text { Reduced } \mathrm{N} / \mathrm{total} \mathrm{N}^{-1} \\
\left(\mathrm{NO}_{3}^{+}+\mathrm{Cl}\right)\left(\mathrm{mmol} \mathrm{kg}^{-1}\right)\end{array}$ & $\begin{array}{r}4152 \\
1084 \\
262 \\
3068 \\
73.8 \\
1346\end{array}$ & $\begin{array}{c}4276 \\
1249 \\
268 \\
3026 \\
70.7 \\
1518\end{array}$ & $\begin{array}{l}+++ \\
+++ \\
+++ \\
+ \\
++ \\
++\end{array}$ \\
\hline $\begin{array}{l}\text { Fresh weight } \\
\mathrm{NO}_{3}^{-}\left(\mathrm{mg} \mathrm{kg}^{-1}\right)\end{array}$ & $\begin{array}{r}120 \\
3352 \\
\end{array}$ & $\begin{array}{r}138 \\
3716 \\
\end{array}$ & $\begin{array}{l}n \\
H \\
H\end{array}$ \\
\hline
\end{tabular}

Table 5. Weight (g per head) and nutrient concentration of lettuce heads at three harvests, as affected by different numbers of nights with illumination of low intensity.

\begin{tabular}{|c|c|c|c|c|c|c|c|c|c|}
\hline \multirow[t]{3}{*}{$\begin{array}{l}\text { Weight or } \\
\text { concentration }\end{array}$} & \multicolumn{6}{|c|}{ Number of nights illuminated (harvest) } & \multicolumn{3}{|c|}{$\begin{array}{l}\text { Stat. eval. of } \\
\text { illumination at harvest }\end{array}$} \\
\hline & \multicolumn{2}{|c|}{1 (2nd) } & \multicolumn{2}{|c|}{5 (3rd) } & \multicolumn{2}{|c|}{$8(4 \mathrm{th})$} & \multirow[t]{2}{*}{ 2nd } & \multirow[t]{2}{*}{ 3rd } & \multirow[t]{2}{*}{ 4th } \\
\hline & none & with & none & with & none & with & & & \\
\hline $\begin{array}{l}\text { Dry weight } \\
\text { Dry weight (\%) }\end{array}$ & $\begin{array}{l}6.53 \\
4.88\end{array}$ & $\begin{array}{l}6.66 \\
5.15\end{array}$ & $\begin{array}{l}7.96 \\
4.83\end{array}$ & $\begin{array}{l}8.67 \\
5.44\end{array}$ & $\begin{array}{l}9.63 \\
5.16\end{array}$ & $\begin{array}{r}10.54 \\
5.85\end{array}$ & 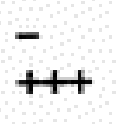 & $\stackrel{+}{++}$ & $\begin{array}{l}++ \\
+++\end{array}$ \\
\hline $\begin{array}{l}\text { Tolal } \mathrm{N}\left(\mathrm{mmol} \mathrm{kg}^{-1}\right) \\
\mathrm{NO}_{3}^{-}\left(\mathrm{mmol} \mathrm{kg} \mathrm{g}^{-1}\right) \\
\mathrm{Cl}^{+}(\mathrm{mmol} \mathrm{kg}) \\
\text { Reduced } \mathrm{N}(\mathrm{mmol}\end{array}$ & $\begin{array}{r}4382 \\
1213 \\
264\end{array}$ & $\begin{array}{r}4345 \\
1192 \\
262\end{array}$ & $\begin{array}{r}4388 \\
1223 \\
306\end{array}$ & $\begin{array}{r}4229 \\
1126 \\
295\end{array}$ & $\begin{array}{r}4380 \\
1111 \\
321\end{array}$ & $\begin{array}{r}4164 \\
1005 \\
308\end{array}$ & $\begin{array}{l}- \\
-\end{array}$ & $\begin{array}{l}+++ \\
++ \\
++\end{array}$ & $\begin{array}{l}+4 \\
++ \\
+\end{array}$ \\
\hline $\begin{array}{l}\mathrm{kg}^{-1} \text { ) } \\
\text { Reduced N/total N } \\
\left(\mathrm{NO}_{3}^{\circ}+\mathrm{Cl}^{-}\right)\end{array}$ & $\begin{array}{l}3169 \\
72.3\end{array}$ & $\begin{array}{l}3154 \\
72.5\end{array}$ & $\begin{array}{l}3164 \\
72.0\end{array}$ & $\begin{array}{l}3103 \\
73.4\end{array}$ & $\begin{array}{l}3269 \\
74.6\end{array}$ & $\begin{array}{l}3159 \\
75.8\end{array}$ & - & $\begin{array}{l}(+) \\
+\end{array}$ & $\stackrel{+}{++}$ \\
\hline$\left(\mathrm{mmol} \mathrm{kg}{ }^{-1}\right)$ & 1477 & 1453 & 1529 & 1421 & 1432 & 1313 & - & + & ++ \\
\hline $\begin{array}{l}\text { Fresh weight } \\
\mathrm{NO}_{3}^{-}\left(\mathrm{mg} \mathrm{kg}^{-1}\right)\end{array}$ & $\begin{array}{r}134 \\
3361\end{array}$ & $\begin{array}{r}130 \\
3806\end{array}$ & $\begin{array}{r}166 \\
3647\end{array}$ & $\begin{array}{r}160 \\
3786\end{array}$ & $\begin{array}{r}187 \\
3539\end{array}$ & $\begin{array}{r}181 \\
3633\end{array}$ & - & + & - \\
\hline
\end{tabular}

that in fresh weight was increased. The chloride concentration of the lettuce was lowered by lighting.

\section{Discussion}

Nitrate in the plant may be present in a metabolic pool in the cytoplasm, or in a storage pool in the vacuole. The main difference between high and low light conditions is probably that nitrate may serve as an osmoticum in the vacuole under low light conditions, compensating for the shortage of soluble carbohydrates. Thus in two 
lettuce cultivars nitrate concentration was inversely related to the concentration of organic acids and sugars (Blom-Zandstra et al., 1988).

In contrast to earlier results for spinach, low light intensities at night were not effective in reducing the nitrate concentration on a fresh weight basis in wintergrown lettuce in this experiment. The difference in results between spinach and lettuce might be partly due to poor light penetration into lettuce heads. Machácková et al, (1985) were able to decrease the nitrate accumulation of lettuce leaves on a fresh weight basis by $12 \%$ and that of spinach by $29 \%$ by illumination of the plants the night before harvest. Benoit \& Ceustermans (1989) had no success in lowering the nitrate concentration in lettuce by lighting with incandescent lamps one day before harvest. According to calculations (data not given), more nitrogen was taken up in the present experiment by the illuminated plants and, as was found for spinach by Steingröver (1986), the fraction of reduced nitrogen in lettuce increased (Table 5). The absolute nitrate concentration on a dry weight basis was reduced, but as a consequence of the increased dry matter percentage this effect was nullified for the nitrate concentration on a fresh weight basis.

The comparison of illuminated and non-illuminated plants in this experiment was complicated by the fact that the non-illuminated plants had to be covered. A possibly higher air humidity and/or air temperature, as follows from the lower dry matter percentage, may have restricted the transport of nitrate to aerial parts of the covered plants, as Steingröver (1986) found in experiments with spinach. Thus a favourable reduction in nitrate accumulation due to illumination may have been obscured.

In the experiment described here the role of $\mathrm{Cl}^{l}$ and $\mathrm{NH}_{4}{ }_{4}$ was studied at the same total ion concentrations in the nutrient solutions. For the control of nitrate accumulation in lettuce, only the presence of ammonium in the solution appeared to be important (Tables 2 and 3). In contrast with earlier results (Van der Boon et al., 1988) chloride did not lower the nitrate concentration in the plant, not even if ammonium was also present in the nutrient solution. The composition of the nutrient solution during the last two weeks had much more pronounced effects on nitrate concentrations than that of the initial solution.

As shown by Tables 2 and 3 the ammonium supply increased the reduced-N concentration and lowered the amount of inorganic osmoticum, as estimated from the sum of $\mathrm{NO}_{3}$ and $\mathrm{Cl}^{-}$, although less markedly. Nitrate may have been replaced by low molecular organic compounds, as the plant tried to maintain turgor. The $\mathrm{Cl}$ addition had no or a small influence on the reduced- $\mathrm{N}$ concentration. but clearly increased the inorganic osmoticum value. The negative correlation between the nitrate and chloride concentrations of the lettuce (correlation coefficients of -0.61 to -0.75 ; increasing with plant age) indicated as expected that nitrate in the vacuole can be replaced by chloride. Illumination and addition of $\mathrm{NH}_{4}{ }^{*} / \mathrm{Cl}$ showed no interaction in their effects on the $\mathrm{NO}_{3}$ and $\mathrm{Cl}^{\cdot}$ accumulation in the vacuole.

Measures to reduce nitrate concentrations in the crop may reduce yield or lower external quality. Such measures are not attractive to growers if there is no financial compensation. With ammonium in the nutrient solution fresh weight was increased (Table 2). In earlier experiments the same was generally found in winter, but not in summer trials (Van der Boon et al., 1990). 


\section{E. G. STEINGROVER, J. W. STEENHUIZEN AND J. VAN DER BOON}

In comparison with a dry weight increase of $9 \%$ due to heating of the the nutrient solution, the increase in total amounts of nitrogen and chloride taken up was somewhat higher, 13 and $12 \%$ respectively, while the nitrate uptake by the lettuce head was much higher $(26 \%)$. Thus the increased nitrogen uptake was accompanied by a relatively low assimilation of nitrate. The increase in nitrate concentration due to heating was rather large in comparison with the decrease due to ammonium in the initial solutions. Previously, only a moderate nitrate accumulation as a result of heating was found (Van der Boon et al., 1990).

It is concluded that lettuce can be produced in winter under glass with a nitrate concentration on a fresh weight basis of $2900 \mathrm{mg} / \mathrm{kg}$. The lowest nitrate contents, without negative effects on yield or quality, were obtained by growing the crop on recirculating nutrient solutions with an ammonium/nitrate ratio of 0.25 initially and of 1.0 in the last two weeks. Heating of the nutrient solution increased the nitrate concentration in the crop. Supplying low light intensities at night during up to 8 nights before harvest time was not effective in further reducing the nitrate concentration on a fresh weight basis, due to an increase in the dry matter percentage. Interactions between illumination at night and the water balance of the crop should receive further attention.

\section{Acknowledgements}

The authors wish to express their appreciation to Ms. E. Jongman for her technical assistance and to Dr. M. van Noordwijk for the helpful discussions and for critically reading the manuscript.

\section{References}

Benoit, F, \& N. Ceustermans. 1989. Recommendations for the commercial production of butterhead lettuce in NFT. Soilless Culture 5: 1-9.

Blom-Zandstra, G. \& J. E. M. Lampe, 1983. The effect of chloride and sulphate salts on the nitrate content in lettuce plants (Lactuca sativa L.). Journal of Plant Nutrition 6: 611-628.

Blom-Zandsıra, M., J. E. M. Lampe \& F. H. M. Ammerlaan. 1988. C and N utilization of two lettuce genotypes during growth under non-varying light conditions and after changing the light intensity. Physiologia Plantarum 74: 147-153.

Clarkson, D. T. \& A. J. Warner, 1979. Relationships between root temperature and the transport of ammonium and nitrate ions by Italian and Perennial Ryegrass (Lolium multiflorum and Lolium perenne). Plant Physiology 64: 557-561.

Frota, J. N, E. \& T. C. Tucker, 1972. Temperature influence on ammonium and nitrate absorption by lettuce. Soil Science Society of America Proceedings 36: 97-100.

Macduff, J. H. \& A. Wild, 1989. Interactions between root temperature and nitrogen deficiency influence preferential uptake of $\mathrm{NH}_{4}^{+}$and $\mathrm{NO}_{3}^{-}$by oilseed rape. Journal of Experimental Botany 40: 195-206.

Machácková, I., Z. Zmrhal \& M. Treková, 1985. Nitrate content in lettuce and spinach leaves in relation to the day-time of harvesting and conditions and duration of storage. (In Czech). Rostlinná Výroba 31: 1151-1155.

Quinche, J.-P.. 1983. Essais de culture de laitues pommées en serre avec des suppléments de lumière artificielle. Revue Suisse de Viticulture d'Arboriculture et d' Horticulture 15: 269-271.

Roorda van Eysinga, J. P. N. L. 1984. Nitrate and glasshouse vegetables. Ferrilizer Research 5: 149-156. 
Steingröver, E. G., 1986. Nitrate accumulation in spinach. Doctoral thesis. University of Groningen, The Netherlands, $84 \mathrm{pp}$.

Steingröver, E., P. Ratering \& J. Siesling, 1986a. Daily changes in uptake, reduction and storage of nitrate in spinach, grown at low light intensity. Physiologia Plantarum 66: 550-556.

Steingröver, E., J. Siesling \& P. Ratering, 1986b. Effect of one night with 'low light' on uptake, reduction and storage of nitrate in spihach. Physiologia Plantarum 66: 557-562.

Van der Boon, J., J. W. Steenhuizen \& E. Steingröver, 1988. Effect of EC, and $\mathrm{Cl}$ and $\mathrm{NH}_{4}$ concentration of nutrient solutions on nitrate accumulation in lettuce. Acta Horticulturae 222: $35-42$.

Van der Boon, J., J. W. Steenhuizen \& E.G. Steingröver, 1990. Growth and nitrogen concentration of lettuce as affected by total nitrogen and chloride concentration, $\mathrm{NH}_{4} / \mathrm{NO}_{3}$ ratio and temperature of the recirculating nutrient solution. Journal of Horticultural Science 65: 309-321. 